niques yielding serviceable castings. Recent work in non-ferrous physical metallurgy has included the equilibria between oxygen and phosphorus in molten copper. Dr. Whittingham is a Cambridge graduate, and in 1942 he joined the British Coal Utilization Research Association and is now the superintendent of the Association's Combustion Department. He has studied particularly the formation of sulphur trioxide during the pre-flame and flame combustion of carbon monoxide, hydrogen and hydrocarbor: gases containing small amounts of sulphur dioxide. This work led to a now theory that sulphur trioxide could be formed in combustion processes as a result of a gas-phase reaction between sulphur dioxide and oxygen atoms. His later work has included spectroscopic observations on flames containing sulphur compounds and on the luminescence of burning carbon, and an examination of the effects of fine smoke particles on combustion gases containing sulphur oxides.

Cadman Memorial Medal : Dr. Robert E. Wilson

The Cadman Memorial Medal of the Institute of Petroleum has been awarded to Dr. Kobert E. Wilson, chairman of the board of the Standard Oil Co. (Indiana). After the presentation of the Medal on June 21, at the Royal Institution, 21 Albemarle Street, London, W.1, Dr. Wilson will give the third Cadman Memorial Lecture, his subject being "Management and Research in the Petroleum Industry". Dr. Wilson was born in Pennsylvania and is a graduate of the Massachusetts Institute of Technology; he began his career as a research associate at the Institute and later was appointed a director of research there. In 1922 he became assistant director of research at the Whiting Refinery of the Standard Oil Company (Indiana), later becoming a director and vice-president of the Company. He was appointed chairman in 1945. During the Second World War Dr. Wilson was chairman of the Committee on Petroleum Economics of the Petroleum Industry War Council.

Engineer-Captain Edgar C. Smith, O.B.E., R.N. (ret.)

Is Nature of April 28 and May 19 are articles by Engineer-Captain Edgar C. Smith on memorials to scientific men in Britain. These articles open a series which we hope to publish during the course of the Festival of Britain, and are the latest of his numerous historical contributions to Nature, Engineering, the Transactions of the Newcomen Society, and other periodicals. Capt. Smith has just entered upon his eightieth year, having been born on May 5, 1872, at Newport Pagnell. His boyhood was spent at Gravesend, where his father, George Charles Hooper Smith, kept a school. After a short period at Finsbury Technical College under John Perry and Silvanus Thompson, he devoted some six years to acquiring a varied workshop experience, mainly in the West Country, and then, at the age of twenty-three, joined the Royal Navy as a direct-entry assistant engineer. In the next twenty-seven years he served in the battleships Trafalgar, Sans Pareil, Barfleur and Magnificent, the cruisers Fearless, Carnarvon and Minerva, the destroyer Orwell, on the staff of the training ship Britannia, and in the Royal Dockyards at Hong Kong and Devonport. He retired in 1922, and has since devoted himself to scientific biography and the history of naval engineering, studies which began forty-five years ago when the Orwell sustained collision damage that kept her in dock at Leith for several months, thus enabling Engineer Lieutenant Smith (as he then was) to explore the libraries and bookshops of Edinburgh and to collect biographical material, some of which he has deposited in the office of Nature. His labours in the field of naval engineering history have been particularly well timed, for he has been the means of recording the personal recollections of many naval engineers whose service dated back to the days when steam was still auxiliary to sail.

\section{Kossuth Awards in Hungary for 1951}

WINNERS of the 1951 Kossuth Awards in Hungary, which are given for outstanding work during the past year, have recently been announced. Fifteen of the Awards are for 20,000 forints and sixty-nine for 10,000 forints, making a total of nearly a million forints (about $£ 30,000$ ). The Awards are divided between four sections on natural sciences, humanities, arts and literature, and social reconstruction, respectively ; those for natural sciences are as follows, the value being 10,000 forints except where otherwise stated. Agricultural Science : Prof. G. Ubrizsy, for the application of Soviet plant-protection methods and his contribution to the book "Handbook of Practical Plant Protection". Botany : Prof. R. Soó, for work in botanical science. Chemistry: Prof. E. Schulek (20,000 forints), for research into chlorocyanide compounds, the theory of absorption indicators and methods of gas analysis; L. Erdoi, for work on the use of ascorbic acids in chemical analysis. Geology: Prof. S. Vitális, for contributions to geological map-making; Prof. A. Földvári, for research into the use of minerals, and the discovery of mineral deposits; Prof. M. Vendel, for work on the classification of ore deposits. Medicine : Prof. Ǒ. Kexpel-Frónius, for research into infantile atrophy and exsiccative toxicosis; Prof. A. Babics, for research into kidney infections. Mathematics : Prof. G. Hajos, for work on the study of group principles; Prof. P. Rózsa, for investigations on recursive functions; G. Alexits, for research into orthogonal series analysis. Physics: Prof. L. Jánossy, for work on cosmic rays; I. Kovács and A. Budó, jointly, for work on the examination of molecular spectra. Technology : J. Kóta, of the Mine Safety Research Institute (20,000 forints), for research into mine explosions; L. Heller, for work on air con. densing systems.

\section{Royal Botanic Gardens, Kew : Exhibition}

By invitation of the director, Sir Edward Salisbury, 477 members of scientific societies and university students attended at the Herbarium and Library of the Royal Botanic Gardens, Kew, during May 4-5. In the absence of the director through illness, the visitors were welcomed by the keeper, Dr. W. B. Turrill, who briefly outlined the history, organization and work of Kew and summarized the objects of the exhibition that had been staged in the three wings of the Herbarium. A large series of beautifully arranged plants and plant specimens illustrated some of the many lines of research on which members of the Kew staff are engaged. 'There were also exhibits of plants of special interest to undergraduate students, who had come from most of the English and Welsh universities. Among the subjects fully demonstrated several may be mentioned. Thirty-nine genera of Coniferæ were represented by living plants, and a large series of rhododendrons in flower showed the range of structure in this genus. The vegetation of South Africa, of British Somaliland, of high moun- 